\title{
An Assessment Of The Use, Benefits And Challenges Of The 'Cash-Lite' Policy, For Construction Projects In Anambra State, Nigeria
}

\section{Fidelis Okechukwu Ezeokoli, MSc}

Department of Building, Nnamdi Azikiwe University, Awka, Anambra State, Nigeria

Stanley Chukwudi Ugochukwu, MSc

Nathan Ndubuisi Agu, PhD

Department of Quantity Surveying, Nnamdi Azikiwe University,

Awka, Anambra State, Nigeria

Samuel Chukwujekwu Akabogu, MSc

Works Department, Nnamdi Azikiwe University Teaching Hospital,

Nnewi, Anambra State, Nigeria

doi: 10.19044/esj.2016.v12n16p313 URL:http://dx.doi.org/10.19044/esj.2016.v12n16p313

\begin{abstract}
The introduction of the 'Cash-Lite; a cashless policy, by the Central Bank of Nigeria in 2011 has changed the modus operandi of the construction industry. This is because the industry is one of the few industries that deal mostly with cash. Hence, this study is aimed at examining the development and implementation of the Nigerian 'Cash-Lite' policy, with a view to ascertain its effects on construction practice. The study examined 300 construction stakeholders using questionnaires. Data obtained from these sources was analysed using charts, table of frequency, mean scores and Ztest. However, the data analysis was aided by a computer database software packages - SPSS Statistic. The study observed that the integration of cashless policy into construction work will boost productivity/construction output via reducing the rate of visit to banks, reducing theft/corruption, reducing project time and encourage prompt settlement of transaction. In addition to this, the study observed that the structure of the industry encourages the integration of this policy to construction but security (cyber theft), lack of knowledge, cost of installation and operation, reliability of the service and supporting services and low public acceptance are the major challenges affecting its adoption in construction. Finally, the study recommends that construction workers and other construction stakeholders should be properly sensitized on the use of cashless tools.
\end{abstract}


Keywords: Anambra State, Cashless Economy, Cash-Lite Policy, Central Bank of Nigeria, Construction Industry

\section{Introduction}

Construction industry may be viewed as that sector of the economy which, through planning, design, construction, maintenance and repair, and operation, transforms various resources into constructed facilities (Isa, Jimoh, \& Achenu, 2013). Simply put, construction industry is a sector of the economy that transforms various resources into constructed physical, economic and social infrastructure necessary for socio-economic development. The industry is an important sector of the economy which makes a significant contribution to Gross Domestic Product (GDP), capital formation, and employment. It has backward and forward linkage effects with several other sectors. In every country, the construction industry constitutes a large part of the economy. Studies has proved that construction contributes between 5 and 10 percent of gross domestic product (GDP), employs up to 10 percent of the working population and is responsible for about half of the Gross Fixed Capital formation (Ogunsemi \& Jagboro, 2006; Ofori, 2012).

Monetary policy refers to the combination of measures designed to regulate the values, supply and cost of money in an economy in consonance with the expected level of economic activity while Fiscal Policy refers to the use of government revenue collection (taxation) and expenditure (spending) to influence the economy (Abiodun, 1999). Common examples of monetary and fiscal policy tools are: taxes, spending, interest rate, reserve requirement, currency peg and open market operations. These policies are used either to increase or decrease aggregate demand and to some extent, increase aggregate supply. The primary objective of fiscal and monetary policy is to regulate/influence the economy of any nation. Thus, government from time to time use it to manage the economy of their nation.

Accordingly, Nigeria government through the Central Bank of Nigeria (CBN) introduced recently the Cash-Lite policy, otherwise known as Cashless policy or e-commerce/banking to regulate her economy. This policy is aimed at reducing (not eliminating) the amount of physical cash (coins and notes) in circulation, and encourage more electronic-based transactions for payments for goods, services, transfers (CBN, 2011). Some of the major reasons for this policy according to CBN are: to drive development and modernization of our payment system, to reduce the cost of banking services (including cost of credit) and drive financial inclusion by providing more efficient transaction options, greater reach and to improve 
the effectiveness of monetary policy in managing inflation and driving economic growth.

Conversely, the construction industry as earlier noted is one of the critical component/sector of any economy. As such, it can easily be influenced by any policy taken by its regulator (i.e. government of that economy). Also, it is generally acknowledged that the industry is one of the few industries that deal most with cash rather than credit/card. Hence, the introduction of this new policy automatically changes the modus operandi of the industry. It is against this backdrop, that this research, studies the effect of this policy on construction practice in Anambra State, Nigeria.

\section{Aim and Objectives of the Study}

The aim of this research is to examine the development and implementation of the Nigerian 'Cash-Lite' policy, with a view to ascertaining its effects on construction projects/works in Anambra state. The specific objectives for this study are:

i. To assess the level of awareness and use of the 'Cash-Lite' policy by construction stakeholders in the study area.

ii. To identify the benefits and challenges of 'Cash-Lite' policy to construction practice in the study area.

iii. To rank the benefits and challenges of 'Cash-Lite' policy in their order of importance.

\section{Research Hypothesis}

The following hypotheses were developed in order to promote the achievement of the purpose of the study.

$\mathbf{H}_{\mathbf{0 1}}$ : The structure of construction industry do not significantly encourage the adoption of the cash-Lite (cashless) policy in construction

$\mathbf{H}_{\mathbf{0 2}}$ : Cash-Lite (cashless) transaction does not significantly affect construction output

\section{Research Methodology}

This study was carried out, using the accidental sampling method, in Anambra state, Nigeria. A total of 300 construction professionals, construction artisans, building materials vendors and suppliers and construction regulators within the study area were sampled. Questionnaires, published/unpublished books, journals and articles were used as data collection instruments. Data obtained from these sources was analysed using charts, table of frequency, Mean scores and Z-test. The Z-test was used to test the research hypotheses, while the data analysis was aided by a computer database software packages - SPSS Statistic. 


\section{The Study Context: Anambra State}

Anambra State is one of the 36 States in Nigeria, located in the southeast geo-political zone of the country. Its name is an anglicized version of the original 'Oma Mbala', the native name of the Anambra River. The indigenous ethnic groups in Anambra state are the Igbo (98\% of population) and a small population of Igala ( $2 \%$ of the population) who live in the North western part of the state (http://www.anambrastate.gov.ng).

The State lies approximately between latitudes $5^{0} 50^{\prime}$ and $6^{0} 45^{\prime}$ North and Longitudes $6^{0} 35^{\prime}$ and $7^{0} 30^{\prime}$ East. Anambra State is in the tropical zone of Nigeria, with two distinct seasons, dry and rainy seasons from December to April and May to October, with July as the rainiest month. Average monthly minimum and maximum temperature ranges from $19.4^{0} \mathrm{C}-36.4^{0} \mathrm{C}$, average monthly relative humidity ranges from $63 \%$ - 92\%, average monthly rainfall ranges from 28.3mm - 363.3mm (Anambra State Bureau of Statistics, 2013). Furthermore, the State shares boundaries with Delta to the West, Imo to the South, Enugu to the East and Kogi to the North. It has a total land mass of 4,887sq.km and situates on the Eastern side of River Niger. The State comprises 177 communities (towns) in 21 Local Government Areas.

The three major towns in the State include: Awka, its capital city, and the Seat of Government, the commercial town of Onitsha and the industrial city of Nnewi. According to the Anambra State Bureau of Statistics (2013), the State has a population of 4,182,032 which makes it the 9th most populous in Nigeria. It also has an 5restimated average population density of 1,500-2,000 persons per square kilometre, making it the second most densely populated state in Nigeria, after Lagos State. With an annual population growth rate of 2.21 percent per annum, Anambra State has over $60 \%$ of its people living in urban areas making it one of the most urbanized places in Nigeria.

National Bureau of Statistics (2006) describes Anambra State as the 2nd most urbanized state in the country, with $62 \%$ of its total population living in urban areas. Over the last two decades the rural/urban migration (contributed by population growth) has posed serious burdens for the State's resources. This pressure is prevalent in the major towns in the state, and as a result, they have become characterized by inadequate and deteriorated amenities, facilities and infrastructure.

Extensive construction activities and concentration of construction industry stakeholders such as clients, contractors, consultants/professionals, construction materials dealers and artisans are also found in the aforementioned towns and other commercial towns such as Ekwulobia. These areas of high construction activities were considered for this study. Thus, the importance of the construction industry in Anambra State has been described succinctly as occupying an important position in the structure of 
the State's economy. Its contribution has over the years represents a reasonable percentage of the Gross Domestic Product (GDP) of the state (2.64\% in 2012 and 2.79\% in 2013) (Anambra State Bureau of Statistics, 2013) and also provides a substantial source of employment, especially for unskilled labour.

The foregoing statistical data underscores the selection of Anambra State as the study area, albeit where the 'Cash- Lite' policy can be included into the State's development plans and hence impact positively on the construction sector.

\section{Literature}

\section{Cashless Policy in Nigeria: Development, Challenges and Prospects}

Cash-less banking according to CBN (2011); Odior and Banuso (2012); Omotunde, Sunday, and John-Dewole (2013); is be defined as that banking system which aims at reducing, not eliminating the amount of physical cash (i.e. notes and coins) circulating in the economy, whilst encouraging more electronic based transactions (payment for goods, services, transfers etc.). In other words, it is a combination of e-banking and cash-based systems. E-banking, according to Boateny and Molla (2006), is the deployment of banking services and products over electronic and communication networks directly to customers. These electronic and communication networks include Automated Teller Machines (ATMs), direct dial-up connections, private and public networks, the Internet, televisions, mobile devices and telephones. While, Cash based economy is an economic system, or part of one, in which financial transactions are carried out in cash rather than credit card.

Nigeria on the other hand, is regarded as a cash-based economy because majority of retail and commercial payments are made in cash. According to a recent CBN survey, cash-related transactions account for 99 percent of customer activity in Nigerian banks today (Odior \& Banuso, 2012). The personal demerits/consequence of carrying cash are enormous. Consequently, the cashless economy policy initiated by the Central Bank of Nigeria led by its Governor; Sanusi Lamido Sanusi on April 2011 and was introduced first in Lagos State, the country's economic hub (Okoye \& Ezejiofor, 2013). The policy took effect in Anambra, Abia, Ogun and Federal Capital Territory on 1st of July 2013, and was implemented nationwide on July 1st 2015 (CBN, 2011).CBN sets a daily limits of cumulative withdraws and lodgements of N150, 000 for individuals and N1, 000,000 for corporate customers (now N500,000 and N3million respectively) (Okoye \& Ezejiofor, 2013).

The justifications for this policy as explained by CBN (2011); Odior and Banuso (2012); Okoye and Ezejiofor (2013) are: 
i. $\quad$ To drive the development and modernization of the payment system in line with Nigeria's vision 2020 goal of being amongst the top 20 economies by the year 2020 .

ii. To reduce the cost of banking services (including cost of credit) and drive financial inclusion by providing more efficient transaction options and greater reach.

iii. To improve the effectiveness of monetary policy in managing inflation and driving economic growth.

iv. To curb the negative consequences associated with high cash usage, with has resulted to a number of challenges across the system. Example of challenges resulting from high-cash usage (not exhaustive) includes: corruption, robberies and cash-related crime, high cost of processing borne by every entity across the value chain, revenue leakage arising from significant handling of cash, inefficient treasury management due to nature of cash processing, limitations of monetary policy due to high volumes of cash outside the formal economy, money-laundering, terrorist funding.

Similarly, Yaqub, Bello, Adenuga, and Ogundeji (2013) outline the expected benefits of the cashless policy as follows:

i. For Customers: Increased convenience/access, more service options, reduced risk of cash-related crimes, cheaper access to (out - of - branch) banking services and access to credit.

ii. For Corporations: Better access to capital due to shorter payment processing times, increased efficiency of payment processes and accounting, reduced revenue leakages and more efficient treasury management.

iii. For Government: Increased tax collections, greater financial inclusion and increased economic growth (positive correlation with increased payment efficiency).

iv. For Banks: Efficiency through electronic payment processing, reduced cost of operations (cash handling) and increased banking penetration (CBN, 2011), reduced risk of carrying cash, help promotes the usage of electronic products, track down all major movement of money including terrorism financing, bribery and all attempts to compromise financial transparency, transaction would be consummated faster, reduced cash flow or movement of cash from one location to the other to effect customer's needs.

\section{Types of Cashless tools}

The following explains the cashless tools used for transactions in Nigeria.

i. Cheques: The use of cheques rises in a cashless economy. All cheques drawn in favour of any beneficiary other than the account owner 
must be presented through $\mathrm{CBN}$ clearing house and the value of cheques must not exceed N10million.

ii. Bank drafts and other bank instruments: In a cashless economy, bank drafts will become the toast of many merchants for big ticket transactions not exceeding N10million. This is because bank draft unlike personal cheques in normal Nigerian parlance, cannot bounce except if they are fraudulent. However, they cannot be paid across the counter and will still be subject to the three days clearing rule of $\mathrm{CBN}$ for cheques.

iii. $\quad$ Automated Teller Machines (ATMs): These are used for making variety of online payments such as utility bills, T.V subscriptions, mobile phone recharges. Customers are advised to keep their ATM cards (Debit and Credit) safe and never to divulge their PINs.

iv. Nigerian Interbank Settlement Scheme (NIBSS)Funds Transfers:It is an online platform where banks exchange value thereby enabling the performance of interbank transfers such as NEFT (NIBSS Electronic Fund Transfer) and NIBSS instant transferring funds between banks for single or multiple beneficiaries for individual amounts not exceeding N10million. NEFT transfers, once effected works with the next available clearing session of $\mathrm{CBN}$ and is received in the beneficiary's account the same day or next working day, but NIBSS instant payments are immediate.

v. $\quad$ Real Time Gross Settlements (RTGS):They are used to transfer sums above N10million in favour of a single beneficiary. It is used for big ticket transactions which must have been effected before noon for most banks if the funds are to reach the recipient bank the same day.

vi. Mobile Money: This product enables the users to conduct funds transfers, make payments or receive balance enquiries on their mobile phones.

vii. $\quad$ Electronic- transfers (E-Transfer): This product enables the users to conduct transaction which are effected via the internet on PCs, laptops and other devices. Customers who have subscribed to internet banking can do basic banking transactions via the web.

viii. $\quad$ Point of Sale (POS) terminals: They are deployed to merchant locations where users swipe their electronic cards through them in order to make payment for purchases or services instead of using raw cash. As the POS terminals are online real-time, the customers bank account is debited immediately for value of purchases made or services enjoyed.

\section{Cashless Economy and the Construction Industry}

The Construction industry is a sector of the economy that transforms various resources into constructed physical economic and social infrastructure necessary for socio-economic development. Studies has shown 
that construction contributes between 5 and 10 percent of gross domestic product (GDP), employs up to 10 percent of the working population and is responsible for about half of the Gross Fixed Capital formation (Ofori, 2012). However, there is a deep concern that the industry as a whole is under-achieving; it has low profitability and invests too little in capital, research and development and training. Too many of the industry's clients are dissatisfied with its overall performance (Egan, 1998). Egan further stresses that the industry fails to meet the needs of modern businesses that must be competitive in international markets, and rarely provides best value for its clients. Hence, there is a need to make radical changes to the processes through which it delivers its projects. These processes according to Egan (1998) should be explicit and transparent to the industry and its clients and should employ techniques that will eliminate waste and increasing value for the customer.

To achieve this reformation in this sector, the cashless policy is a move in the right direction. The introduction of this policy will help to solve some of the chronic problems in the industry. Some of the benefits of this policy to the construction industry are:

- $\quad$ Reduction of Cost of Production: Cashless transactions are better than cash transactions. Thus, it will contribute significantly to the reduction of cost of production by reducing losses incurred through stealing, overpayment, misplacement and corrupt practices by contractors and suppliers. A recent report in the UK according to Stewart (2000) suggests that if the construction industry adopted e- business, they could expect to save up to $2.3 \%$ of building costs.

- Reduction of the Time needed for the Realisation of a Construction Project: The integration of cashless policy to construction processes will quicken transaction in construction. That is, time spent in banks to withdraw before going to market will be eliminated; time spent on paying workers will also be eliminated. Thus, it ensures that materials get to site on time and wastage of man-hour is reduced. These concur with the suggestion of Stewart (2000); that integration of e-commerce to construction practice will reduce completion time by $15 \%$.

- Improvement of the Work Conditions of the Construction Workers and Improved Hygiene on Site: The use of cashless policy will integrate other computer based technology into construction process. Such technology according to Stewart (2000) is the Wireless Sensor. These instruments will help monitor the progress of the project by collecting realtime data using a computer. Also, cashless policy will help - eliminating the bacterial spread through handling notes and coins on site because most site workers in the study area and Nigeria as a whole, hardly wash their hands before eating in site. 
- Prompt settlement of Transactions: E-banking speeds up settlement of transactions both locally and internationally. Thus, saving time and ensuring convenience. One may not need to visit bank and queue up to be attended to before settlement of a construction transaction.

- $\quad$ Reduction in the frequency of visit to the Banks: Unlike in the past, customers can now transact their banking businesses in branches nearest to them and can also withdraw money from any ATM including those located outside the bank where they have accounts. They can also transact banking business at home with the aid of telephones, tablet and computer.

- Reduction of Theft/Corruption: Since robbers are attracted by volume of cash movement, the use of alternative electronic payment system will no doubt reduce the incidence of robbery in the society. With cashless policy, cash/money can easily be tracked, hence help to curb sharp practices in building construction.

The introduction of the cashless policy into construction works has a lot of imminent obstacles. These challenges/obstacles are:

- Cost: 'Cash-Lite' technology is a relatively new technology in Nigeria and in the study area particularly and as a result there are many questions related to the cost of training and redeployment of the cashless technology to construction works.

- Reliability: Because the Cashless technology is relatively new in Nigeria, worsened by epileptic power supply and poor internet services, there are doubts over its reliability, as there may be failures when this technology is deployed on the construction site.

- $\quad$ Lack of Knowledge: The people who work on construction sites may not have the required knowledge in order to use this technology. Cashless technologies are relatively new in Nigeria and publications related to its application in the construction industry are not much. Consequently, it may be difficult for the construction industry to adopt this technology.

- Fear of Employers for Lower Productivity and Higher Cost: Employers do not want to take the risk of implementing a very new technology on the construction site because they think that the possible lack of knowledge by the construction professionals/workers of the details of the specific technology will result in lower productivity and loss of profit.

- $\quad$ Security: The issues of malware, hackers, fraudsters, viruses and identity theft scare people away from this technology especially among the people with low educational background, which are found on most construction sites.

- Low public acceptance: Situations such as religious sentiments, phobia for internet/computer service, encouragement of excessive 
withdrawals and situation where customers are debited by the ATM with withdrawals not supported by cash, have made people develop cold feet towards adopting the new technology and construction workers are not exempted.

\section{Literature Gaps}

A close looks at the synthesis of literature shows some glaring lacuna, which this study intends to fill. It is these gaps found in literature that justifies this research.

(a) Undoubtedly, studies have been carried out by authors on the use, benefits, challenges and even prospects of the 'Cash-Lite' policy in Nigeria. However, there is presently no study in Nigeria that examines how the construction industry has responded to the cashless policy, in other words, the use, effects, challenges and benefits to construction projects and stakeholders are not fully known.

(b) Use of cashless tools in Nigeria is far below international best practices, especially amongst construction artisans in Nigeria. Hence, the need to more enlightenment or awareness in that regard.

(c) Presently, studies on cashless procedures have not been conducted in sufficient details for the peculiar needs and nature of construction projects.

\section{Data Presentation, Analysis and Discussion}

\section{Questionnaires Distribution}

Table 1: Questionnaires Distribution

\begin{tabular}{ccc}
\hline Options & Frequency (No) & Response Rate (\%) \\
\hline No Distributed & 300 & 100.00 \\
No Returned & 240 & 80.00 \\
Difference & 60 & 24.00 \\
\hline
\end{tabular}

Source: Researchers’ Field Survey (2015).

From table 1, three hundred questionnaires were distributed but two hundred and forty were returned. The difference between the number distributed and Number returned is $24 \%$, meaning that $76 \%$ were completed and returned. Hence, 76\% falls within the acceptable margin (Okolie, 2011).

\section{Awareness of the Cash-Lite Policy among Construction Stakeholders}

Table 2: Awareness of the Cash-Lite Policy among Construction Stakeholders

\begin{tabular}{ccc}
\hline Options & Frequency (NO) & Response Rate (\%) \\
\hline Yes & 233 & 97.08 \\
No & 7 & 2.92 \\
\hline Total & 240 & 100.00 \\
\hline
\end{tabular}

Source: Researchers’ Field Survey (2015). 
Table 2 shows that the $97.08 \%$ of the respondents have heard of the cashless policy but $2.92 \%$ of the respondent indicated that they have not. Thus, its means that majority of construction stakeholders have heard of the cashless policy.

\section{Source of the awareness of the Cash-Lite Policy}

Table 3: Source of the awareness of the Cashless Policy

\begin{tabular}{ccc}
\hline Options & Frequency (NO) & Response Rate (\%) \\
\hline Media & 210 & 87.50 \\
Friends & 20 & 8.33 \\
Lectures/Classroom & 0 & 0.00 \\
Conferences & 10 & 4.16 \\
\hline Total & 240 & 100.00 \\
\hline
\end{tabular}

Source: Researchers’ Field Survey (2015).

The response in table 3 indicates that $87.50 \%$ got to know about this policy through media. $8.33 \%$ and $4.16 \%$ learnt of this policy through friends and conference respectively. It is observed that the media has done a lot by creating awareness about this policy.

\section{Ratings of the use of the Cashless Tools}

Table 4: Ratings on the use of the Cashless Tools (in percent)

\begin{tabular}{|c|c|c|c|c|c|}
\hline \multirow[b]{3}{*}{ Cashless Tools } & \multicolumn{5}{|c|}{ Very Often.............................................Rarely } \\
\hline & 5 & 4 & 3 & 2 & 1 \\
\hline & \multicolumn{5}{|c|}{ Ratings (in percent) } \\
\hline Cheques & 16.67 & 16.67 & 12.50 & 16.67 & 37.49 \\
\hline $\begin{array}{l}\text { Bank drafts and other bank } \\
\text { instruments }\end{array}$ & 12.50 & 20.83 & 25.00 & 16.67 & 25.00 \\
\hline $\begin{array}{c}\text { Automated Teller Machines } \\
\text { (ATM) }\end{array}$ & 82.61 & 4.34 & 8. 70 & 0.00 & 4.34 \\
\hline $\begin{array}{l}\text { Nigerian Interbank } \\
\text { Settlement Scheme (NIBSS) }\end{array}$ & 0.00 & 12.50 & 37.50 & 4.17 & 45.83 \\
\hline $\begin{array}{l}\text { Real Time Gross } \\
\text { Settlements (RTGS) }\end{array}$ & 0.00 & 4.17 & 66.67 & 0.00 & 29.17 \\
\hline Mobile Money & 12.5 & 12.5 & 20.83 & 48.00 & 29.17 \\
\hline E- transfers & 12.5 & 16.67 & 20.83 & 37.50 & 12.50 \\
\hline Point of Sale (POS) & 8.33 & 12.50 & 50.00 & 25.00 & 4.17 \\
\hline
\end{tabular}

Table 4 shows that the cashless tool used often is the Automated Teller Machines (ATM) (86.95\%). This is followed by Bank drafts and other bank instruments (33.66\%) and cheques (33.34\%). However, mobile money (77.17\%), Cheques (54.16), Nigerian Interbank Settlement Scheme (NIBSS) (50\%), E-transfer (50\%) are not often in use but most of the respondents rarely use Nigerian Interbank Settlement Scheme (NIBSS) (45.83\%). 


\section{Ratings of the expected benefits from the Cash-Lite Policy}

Table 5: Ratings on the expected benefits from the Policy (in percent)

\begin{tabular}{|c|c|c|c|c|c|c|c|}
\hline \multirow{4}{*}{ Expected Benefits } & \multicolumn{5}{|c|}{ Strongly agree................Strongly disagree } & \multirow{4}{*}{ M } & \multirow[b]{4}{*}{$\mathbf{R}$} \\
\hline & 5 & 4 & 3 & 2 & 1 & & \\
\hline & \multicolumn{5}{|c|}{ Ratings (in percent) } & & \\
\hline & & & & & & & \\
\hline $\begin{array}{l}\text { Reduction of cost of } \\
\text { production }\end{array}$ & 25.00 & 33.33 & 16.67 & 20.83 & 4.17 & 3.54 & $5^{\text {th }}$ \\
\hline $\begin{array}{l}\text { Reduction of the time needed } \\
\text { for the Realisation of a } \\
\text { construction project }\end{array}$ & 25.00 & 62.50 & 0.00 & 8.33 & 4.17 & 3.96 & $4^{\text {th }}$ \\
\hline $\begin{array}{l}\text { Improvement of the work } \\
\text { conditions of the construction } \\
\text { workers/ improved hygiene } \\
\text { on site }\end{array}$ & 12.50 & 29.17 & 20.83 & 33.33 & 4.17 & 3.12 & $6^{\text {th }}$ \\
\hline $\begin{array}{c}\text { Prompt settlement of } \\
\text { transactions }\end{array}$ & 50.00 & 25.00 & 16.67 & 8.33 & 0.00 & 4.00 & $3^{\text {rd }}$ \\
\hline $\begin{array}{l}\text { Reduction in the frequency of } \\
\text { visit to the Banks }\end{array}$ & 66.67 & 25.00 & 0.00 & 4.17 & 0.00 & 4.38 & $1^{\text {st }}$ \\
\hline Reduction of theft/corruption & 45.83 & 45.83 & 4.17 & 4.17 & 0.00 & 4.33 & $2^{\text {nd }}$ \\
\hline
\end{tabular}

From the answers displayed in Table 5, the respondents feeel that the cashless policy will reduce the rate of visit to Banks (91.67\%); reduce theft/corruption (91.66\%); reduce project time (87.50\%) and encourage prompt settlement of transactions (75\%) respectively. Nonetheless, 25\% of the respondents were of opinion that this policy will not reduce the cost of production. From the table 5 also, using mean score, reduction in the frequency of visit to the Banks ranked first and improvement of the work Conditions of the construction workers/ improve hygiene on site ranked least.

\section{Challenges facing the adoption of the Cash-Lite Policy in Construction}

Table 6: Ratings on the challenges affecting the adoption of the Cash-Lite Policy in Construction.

\begin{tabular}{|c|c|c|c|c|c|c|c|}
\hline \multirow[b]{3}{*}{ Challenges } & \multicolumn{5}{|c|}{ Strongly agree...............Strongly disagree } & \multirow{3}{*}{$\mathbf{M}$} & \multirow{3}{*}{$\mathbf{R}$} \\
\hline & 5 & 4 & 3 & 2 & 1 & & \\
\hline & & \multicolumn{4}{|c|}{ Ratings (in percent) } & & \\
\hline Cost & 20.83 & 45.83 & 20.83 & 12.50 & 4.17 & 3.79 & $3^{\text {rd }}$ \\
\hline Reliability & 16.67 & 41.67 & 20.83 & 20.83 & 0.00 & 3.54 & $4^{\text {th }}$ \\
\hline Lack of Knowledge & 25.00 & 58.33 & 4.17 & 12.50 & 0.00 & 3.96 & $2^{\text {nd }}$ \\
\hline Fear of Employers for Lower & 0.00 & 25.00 & 37.50 & 29.17 & 8.33 & 2.79 & $6^{\text {th }}$ \\
\hline Productivity and Higher Cost & & & & & & & \\
\hline Security & 37.50 & 45.83 & 12.50 & 4.17 & 0.00 & 4.17 & $1^{\mathrm{st}}$ \\
\hline Low public acceptance & 16.67 & 26.47 & 20.83 & 25.00 & 0.00 & 3.02 & $5^{\text {th }}$ \\
\hline & & eutral; & & & & & \\
\hline
\end{tabular}


From the responses in table 6, it can be seen that the respondents were of the opinion that security (83.33\%), lack of knowledge (83.33\%), cost (66.66\%), reliability (58.34\%)and low public acceptance $(43.14 \%)$ are the major challenges affecting the adoption of this policy in construction practice. Conversely, $37.55 \%$ of the respondents felt that fear of employers for lower productivity and higher cost is not a major challenge in adopting cashless policy in construction work. Hence, it's seen that security with a mean score of 4.17 ranked first among the challenges facing adoption of cashless policy in construction. But fear of employers for lower productivity and higher cost with a mean score of 2.79 ranked least.

\section{Test of Hypotheses}

Table 7: Respondents' perception of the Cash-Lite Policy on Construction Practice

\begin{tabular}{|c|c|c|c|c|c|c|c|c|}
\hline \multirow{3}{*}{ Statement } & \multicolumn{5}{|c|}{$\begin{array}{c}\text { Strongly agree................Strongly } \\
\text { disagree }\end{array}$} & \multirow[t]{3}{*}{$\mathbf{M}$} & \multirow[t]{3}{*}{ TS } & \multirow[t]{3}{*}{$\mathbf{C V}$} \\
\hline & 5 & 4 & 3 & 2 & 1 & & & \\
\hline & \multicolumn{5}{|c|}{ Ratings (in percent) } & & & \\
\hline $\begin{array}{l}\text { The structure of the } \\
\text { construction industry do } \\
\text { not significantly } \\
\text { encourage the adoption } \\
\text { of the cashless policy. }\end{array}$ & 12.50 & 33.33 & 8.33 & 33.33 & 12.50 & \multirow[t]{2}{*}{$\begin{array}{l}3.00 \\
3.67 \\
\end{array}$} & 29.46 & 1.96 \\
\hline $\begin{array}{c}\text { Cashless transaction } \\
\text { does not significantly } \\
\text { affect construction } \\
\text { output }\end{array}$ & 33.33 & 29.17 & 8.33 & 29.17 & 0.00 & & 29.93 & 1.96 \\
\hline $\begin{array}{r}* 1 \text { = Strongly Disagre } \\
\mathrm{M}\end{array}$ & 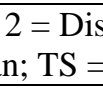 & ree; & tic & $\mathrm{V}=$ & $\begin{array}{l}\text { ee; } \\
\text { al }\end{array}$ & & & \\
\hline
\end{tabular}

\section{Hypothesis 1:}

$\mathbf{H}_{01}$ : The structure of construction industry does not significantly encourage the adoption of the cashless policy.

$\mathbf{H}_{11}$ : The structure of construction industry significantly encourages the adoption of the cashless policy.

\section{Decision Rule}

Reject $H o$ if $Z \geq Z 1-\alpha$. Where $Z=$ the test statistic, $\alpha .=0.05$ (at 5 percent level of significance) and $Z 1-\alpha=$ the critical value. But in this analysis, Z1- $\alpha$ is given as 1.96 (the critical value) at 5 percent level of significance.

This is a one tail or one sided test. Using the SPSS package for the calculations, the test statistic yielded $\mathrm{Z}=29.46$ (see Table 3.7) 


\section{Decision/Conclusion}

Since $Z=29.46$ is greater than 1.96 , the evidence here is statistically significant and so the null hypothesis is rejected. That is; the structure of construction industry does not significantly encourage the adoption of the cashless policy. Thus, the structure of the construction industry encourages the adoption of the cashless policy.

\section{Hypothesis 2:}

$\mathbf{H}_{\mathbf{0 1}}$ : Cashless transaction does not significantly affect construction output $\mathbf{H}_{11}$ : Cashless transaction significantly affects construction output.

\section{Decision Rule}

Reject Ho if $Z \geq Z 1-\alpha$. Where $Z=$ the test statistic, $\alpha$. $=0.05$ (at 5 percent level of significance) and $Z 1-\alpha=$ the critical value. But in this analysis, Z1- $\alpha$ is given as 1.96 (the critical value) at 5 percent level of significance.

This is a one tail or one sided test. Using the SPSS package for the calculations, the test statistic yielded $\mathrm{Z}=29.93$ (see Table 7)

\section{Decision/conclusion}

Since $\mathrm{Z}=29.93$ is greater than 1.96 , the evidence here is statistically significant and so the null hypothesis is rejected. That is; Cashless transaction does not significantly affect construction output. Hence, Cashless transaction significantly affects construction output.

\section{Conclusion and Recommendations:}

Based on the findings of this study, the following conclusions were drawn:

- $\quad$ Most of the construction personnel are aware of the cashless policy, majority learnt about the policy via the media. The study observed that a greater percentage of construction stakeholders often make use Automated Teller Machines (ATM). However, other cashless tools such as Bank drafts and other bank instruments, cheques, Nigerian Interbank Settlement Scheme (NIBSS), E-transfer and mobile money are not often used when compared to the rate of use of the ATM.

- Introduction of cashless policy will reduce the rate of visit to Banks, reduce theft/corruption, reduce project time and encourage prompt settlement of transactions. Thus, with this in place, productivity (output) will be increased and cost of production will be reduced because, cash flow can easily be monitored and tracked.

- $\quad$ Security (cyber theft), lack of knowledge of construction workers especially artisans and building materials vendors on the use of these tools, 
cost of installation and operation, reliability of the supporting services such as network providers and low public acceptance are the major challenges affecting the adoption of this policy to construction practice. In spite of these imminent challenges, the study observed that the structure of the industry encourages the application of this policy to construction work.

- $\quad$ Finally, the study recommends proper sensitization of construction workers and other construction stakeholders on the use of cashless tools, more effort to be to made in reducing cyber-crime/theft and finally, internet service providers should ensure that effective and efficient network service is maintained all times at reduced tariffs.

\section{Contribution to knowledge}

The key contributions to the body of knowledge from this study include:

a) The research has generated a quantitative and qualitative evaluation of 'Cash-Lite' usage on Nigerian construction projects.

b) The research has provided an understanding of the benefits, barriers and challenges of the 'Cash-Lite' policy in the Nigerian construction industry.

c) The research has increased the awareness and perception of cashless policy by construction stakeholders in Nigeria.

d) The research has identified the adoption of the cashless policy and procedures as a missing link in the Nigerian construction industry; a lacuna that has lowered created gaps in the industry. Therefore, this research has opened a window of opportunities for researchers in this area of study.

e) The research has proved that lack of the Nigerian construction sector implementation of the 'Cash-Lite' policy in Nigerian construction projects

\section{References:}

Abiodun, A.O. (1999). The role of monetary and fiscal policies of Government in the Development of the Nigerian Economy in the 90's (Unpublished masters thesis), Federal University of Technology, Akure, Nigeria.

Anambra State Bureau of Statistics. (2013). Statistical year book. Awka: Author.

Central Bank of Nigeria (CBN). (2011). The new cash policy. Abuja: Author. Retrieved from http://www.cenbank.org/Referal.asp?ppath=http://www.cenbank.org/cashles s/Default.asp

Egan, J. (1998). Rethinking construction: The report of the construction task force on the scope for improving the quality and efficiency of the UK construction industry. Retrieved from http://www.constructingexcellence.org.uk 
Isa, R.B., Jimoh, R.A., \& Achenu, E. (2013). An overview of the contribution of construction sector to sustainable development in Nigeria. International Journal of Business Management, 1(1), 1-6.

National Bureau of Statistics (NBS). (2006).Poverty and livelihood in Anambra State. Abuja: Author.

Odior, E.S., \& Banuso, F.B. (2012). Cashless banking in Nigeria: Challenges, benefits and policy implications. European Scientific Journal, 8 (12), $202-212$.

Ofori, G. (2012). Developing the Construction Industry in Ghana: The case for a central agency. Singapore: National University of Singapore Press.

Ogunsemi, D.R., \& Jagboro, G.O. (2005).Time-cost model for building projects in Nigeria. Construction Management and Economics, 24, 253-258.

Okolie, K. C. (2011). Performance evaluation of buildings in educational Institutions: A case of universities in south-east Nigeria (Unpublished doctoral thesis), Nelson Mandela Metropolitan University, Port Elizabeth, South Africa.

Okoye, P.V., \& Ezejiofor, R. (2013). An appraisal of cashless economy policy in the development of the Nigerian economy. Research Journal of Finance and Accounting, 4 (7), 237 - 252.

Omotunde, M., Sunday, T., \& John-Dewole, A.T.(2013). Impact of cashless economy in Nigeria. Greener Journal of Internet, Information and Communication Systems, 1 (2), 40-45.

Stewart, P. (2000), The role of E-commerce systems for the construction Industry. Australian Journal of Construction Economics and Building, 12(3), $24-36$.

Yaqub, J.O., Bello, H.T., Adenuga, I.A., \& Ogundeji, M.O. (2013). The cashless policy in Nigeria: Prospects and challenges. International Journal of Humanities and Social Science, 3 (3), 200 - 212 